\title{
Reducing bycatch in the South African pelagic longline fishery: the utility of different approaches to fisheries closures
}

\author{
Hedley S. Grantham ${ }^{1, *}$, Samantha L. Petersen ${ }^{2,3}$, Hugh P. Possingham ${ }^{1}$ \\ ${ }^{1}$ The University of Queensland, The Ecology Centre, St. Lucia, Queensland 4072, Australia \\ ${ }^{2}$ WWF Responsible Fisheries Programme, PO Box 50035, Waterfront, Cape Town 8001, South Africa \\ ${ }^{3}$ DST/NRF Centre of Excellence at the Percy FitzPatrick Institute of African Ornithology, University of Cape Town, \\ Rondebosch 7701, South Africa
}

\begin{abstract}
Seabirds, turtles and sharks are often of conservation concern because they are frequently bycatch in fisheries. Fisheries managers shifting from a target species focus to an ecosystembased approach are being required to consider the impact of fisheries on non-target species. There are a range of complementary management tools that help reduce bycatch, such as gear restrictions, temporal restrictions, and bycatch reduction devices. One management approach that is increasingly being considered is fisheries closures. We tested the utility of 3 closure approaches for the improved protection of bycatch species in the South African pelagic longline fishery. As there was some variation where and when different groups of bycatch species were caught, we found that temporary spatial closures were the most effective strategy for both protecting bycatch and minimizing the cost to fishers. This is logical because having mobile closures in space and time provides more flexibility than permanent spatial closures or seasonal closures. However these benefits need to be traded off against the costs and problems of implementing temporary spatial closures. Of the 2 sub-optimal strategies, we discovered that seasonal closures are significantly less effective than spatial closures.
\end{abstract}

KEY WORDS: Bycatch $\cdot$ Marine protected area $\cdot$ Conservation planning $\cdot$ Ecosystem-based fisheries management $\cdot$ Fisheries closure $\cdot$ Threatened species

\section{INTRODUCTION}

Commercial fishing in offshore ecosystems has a negative impact in 3 possible ways: on the species they target, on bycatch and by reducing the prey base for species that consume the fish the fishery is catching (Croxall \& Gales 1998, Myers \& Worm 2003, Worm et al. 2003, Lewison et al. 2004, Barker \& Schleussel 2005). There is increasing recognition that fisheries management should shift from a target-species approach to an ecosystem-based one where ecosystems are managed holistically across all user sectors (Botsford et al. 1997, Pikitch et al. 2004, Morishita 2008). The United Nations Convention on the Law of the Seas makes it a mandate for countries to implement ecosystem-based fisheries management. This requires an assessment not only of fish stocks and how they interact with each other, but also of the bycatch of nontarget species and the impact on competitors with the fishery (Pikitch et al. 2004, Smith et al. 2007).

Spatial conservation strategies, which have a long history in management of terrestrial ecosystems, are being used more frequently in marine ecosystems (Carr et al. 2003) and are particularly relevant for ecosystem-based management (Pikitch et al. 2004). Numerous studies have demonstrated the benefits of spatial management, e.g. marine protected areas, for both fisheries management and for the conservation of coastal marine ecosystems (Halpern \& Warner 2002, Gell \& Roberts 2003, Hilborn et al. 2004, Roberts et al. 2005). However, the application of spatial management to offshore ecosystems remains limited and its 
effectiveness is uncertain (Mills \& Carlton 1998, Worm et al. 2003). A potential obstacle associated with applying spatial management in offshore areas is the apparent spatial and temporal dynamics characteristic of these ecosystems (Hyrenbach et al. 2000). Nevertheless, recent studies provide useful suggestions for applying spatial management in these systems (e.g. Alpine \& Hobday 2007). One proposed solution is the ability to move spatial management zones accordingly to features of interest (Hyrenbach et al. 2000, Hobday \& Hartman 2006).

There is global concern about the bycatch of seabirds, turtles and sharks (Croxall \& Gales 1998, Baker et al. 2007, Gilman et al. 2008). In South Africa, the pelagic longline fishery that targets tunas Thunnus spp. and swordfish Xiphias gladius kill a significant number of non-target species as bycatch (Petersen et al. 2007). We selected 7 of the most frequently caught bycatch species all listed by International Union for Conservation of Nature (IUCN) as threatened or near threatened. This included 3 seabirds, the blackbrowed albatross Thalassarche melanophrys (endangered), the shy albatross T. cauta/steadi (near threatened) and the white-chinned petrel Procellaria aequinoctialis (vulnerable); 2 turtles, the leatherback Dermochelys coriacea (critically endangered) and the loggerhead Caretta caretta (endangered); and 2 sharks, the short-finned mako Isurus oxyrinchus (vulnerable) and the blue Prionace glauca (near threatened). Many of these species are caught as bycatch in significant numbers globally; for example, whitechinned petrels and black-browed albatross are 2 of the most caught seabirds worldwide (Kock 2001).

We compared the utility of 3 management approaches to help protect these bycatch species from longlining in South Africa. First, we consider the traditional option of temporarily closing the entire fishery. The second approach is a system of permanent spatial closures, more traditional marine protected areas. The third approach is a system of temporary spatial closures where different areas are closed to fishing at different months of the year. We envisage that this case study will be a useful basis for managing longline bycatch in other regions worldwide.

\section{MATERIALS AND METHODS}

The study area was the South African exclusive economic zone (Fig. 1). Data were collected by independent fishery observers aboard pelagic longline vessels operating in the South African Pelagic Longline Fishery from 1998 to 2005. This information included a record for each longline set, including operational information such as date, position and number of

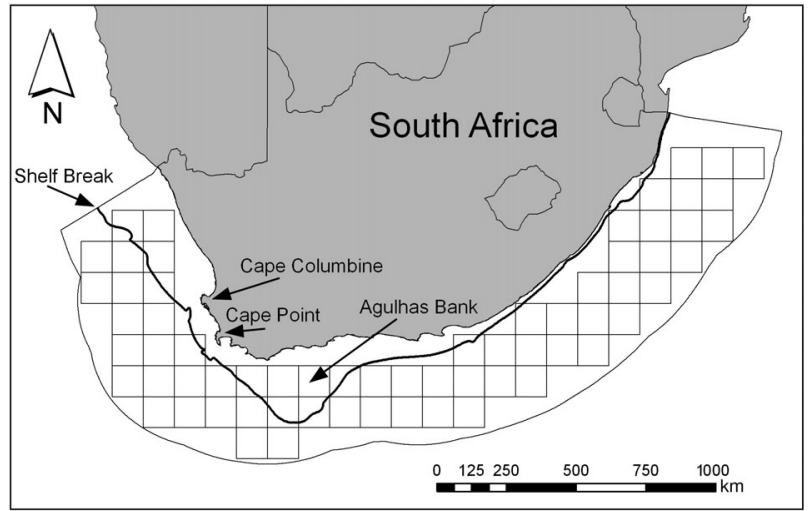

Fig. 1. Study area based on South Africa's exclusive economic zone. Sites are $1^{\circ}$ grid cells. These were used as candidate areas for selecting fisheries closures when space was considered

hooks, and the count of each target and bycatch species captured. To compare the utility of different types of closures we used catch rates averaged over all years, divided by observed fishing effort and reported as the numbers of animals caught per 1000 hooks for each spatial or temporal unit of interest.

Optimization of different fisheries closures. To investigate the utility of the 3 approaches (temporary, permanent spatial and temporary spatial) to fisheries closures we defined the general objective function as:

subject to:

$$
\operatorname{Min} \sum_{j} \sum_{t} C_{j t} X_{j t}
$$

$$
\sum_{j} \sum_{t} a_{i j t} X_{j t} \geq T_{i}
$$

where $C_{j t}$ is the cost of closing site $j$ in time $t, a_{i j t}$ is the bycatch avoided by closing site $j$ in month $t$ for bycatch species $i_{1} T_{i}$ is the target bycatch reduction for species $i_{\text {, }}$ and $X_{j t}$ is the control variable where $X_{j t}=1$ when we close site $j$ in month $t$ and $X_{j t}=0$ when site $j$ is open for fishing in month $t$. For temporary closures, all sites are closed for a set of months, for permanent spatial closures a chosen subset of sites is closed permanently, and for temporary spatial closures there are no constraints on the control variables $x_{j t}$ other than being either 1 or 0 .

The study area was divided into 65 sites, which were our candidate areas for selection. We chose $1^{\circ}$ squares due to the resolution of data and length of longline sets. We included only sites that were fully contained within the region and removed any smaller than $1^{\circ}$ due to land or political boundaries (Fig 1). We assume that temporary closures are by month, consistent with the data we had.

We calculated the average catch rate of all 7 bycatch species for any given site and or time, depending on the type of closure and set a quantitative target for each 
species using the entire dataset. These targets were set as 30,50 and $80 \%$ of the summed catch rate across time and/or space. We varied these to determine the influence of target size on the longline fishery.

To minimize the cost of closures to the longlining industry we developed a cost metric $c_{j t}$ that is the sum of the average catch rate of tuna and the average catch rate of swordfish in site $j$ for month $t$. The higher the cost, the more impact it is likely to have on the longlining industry, assuming that past catch rates reflect future ones. We calculated this metric across time and or space depending on the type of closure. In essence, the aim of the problem is to meet all the bycatch reduction targets for minimum economic cost.

We used the conservation planning software Marxan (Possingham et al. 2000, Game \& Grantham 2008) to select time and or space to achieve bycatch reduction targets for minimum cost. The software does this by minimizing a multivariate objective function (see Possingham et al. 2000, Game \& Grantham 2008 for more technical details on the algorithm and software). The objective function is a combination of the total cost of selection, a penalty for any of the targets that are not met. The selection algorithm used in this software is simulated annealing (Possingham et al. 2000).

Marxan was run 1000 times with 1000000 iterations per run to find both the 'best solution' and the 'selection frequency' for each scenario. The 'best solution' is the set of control variables, $x_{j t}$, that best achieved the objective function over all runs. As Marxan provides only a nearoptimal solution, different solutions were provided by the 1000 runs. The 'selection frequency' solution shows the number of times a particular control variable was selected across all 1000 runs and provides an indication of conservation importance. For example, in the case of permanent spatial closures, if a site has a selection frequency of 798, then it was selected 798 out of 1000 runs.

\section{RESULTS}

\section{Temporal patterns of catch}

Swordfish are caught predominantly in the first half of the year and tunas more in the middle of the year (Fig. 2a,b). We found that the catch rates for bycatch species varied considerably between species and months (Fig. 2c-i). Black-browed albatrosses were caught all year, but chiefly from March to June. Shy albatross also were also caught throughout the year, but peaked in April. White-chinned petrels were caught all year, but mainly June to October and reached a maximum in September. Catch rates for leatherback turtles were highest November to June, but there were no catches in February and March.
Loggerhead turtles were caught primarily in May, June and November. Short-finned makos and blue sharks were caught all year round.

\section{Spatial patterns of catch}

We found the areas with the highest target species were largely on the east and west sections of the study region for swordfish and somewhat ubiquitous for tunas (Fig. 3a,b). This resulted in a fairly spatially heterogeneous cost metric (Fig. 3c) that overlapped considerably with areas of high catch for most bycatch species (Fig. 3d-j). The black-browed and shy albatrosses had a similar spatial catch distribution, largely along the shelf in the western section of the study region. White-chinned petrels were caught off the south and east coasts. Both turtle species were caught in relatively fewer areas than the other species with no apparent pattern where they were caught. Both shark species were caught across most of the study region but less so in the eastern section of our study region.

\section{Fisheries closures}

For temporary closures, we found that 4,5 and 9 mo were required to achieve a 30,50 and $80 \%$ bycatch reduction target, respectively (Table 1 ). The most frequently selected months across all scenarios were January, May, June, September and November.

For permanent spatial closures in general, we found the areas of highest importance were located in the west and southeastern sections of our study region and particularly offshore from Cape Point and Cape Columbine (Fig. 4). This was consistent when applying different targets. Predictably, an increase in reduction target increased both the area and cost of the solution (Fig. 5).

For temporary spatial closures using a $50 \%$ bycatch reduction target we found the most important areas were to some extent different depending on the month, but were generally located in the western section and, to a lesser extent, in the eastern section of the study region (Fig. 6). More sites were required in August, September and November than the other months, indicating the importance of these months. July required the least number of sites. Increasing the reduction target increased the cost to the longlining industry (Fig. 5)

\section{Comparison of different fisheries closures}

We found for all bycatch reduction targets $(30,50$ and $80 \%$ ) that temporary spatial closures have the 

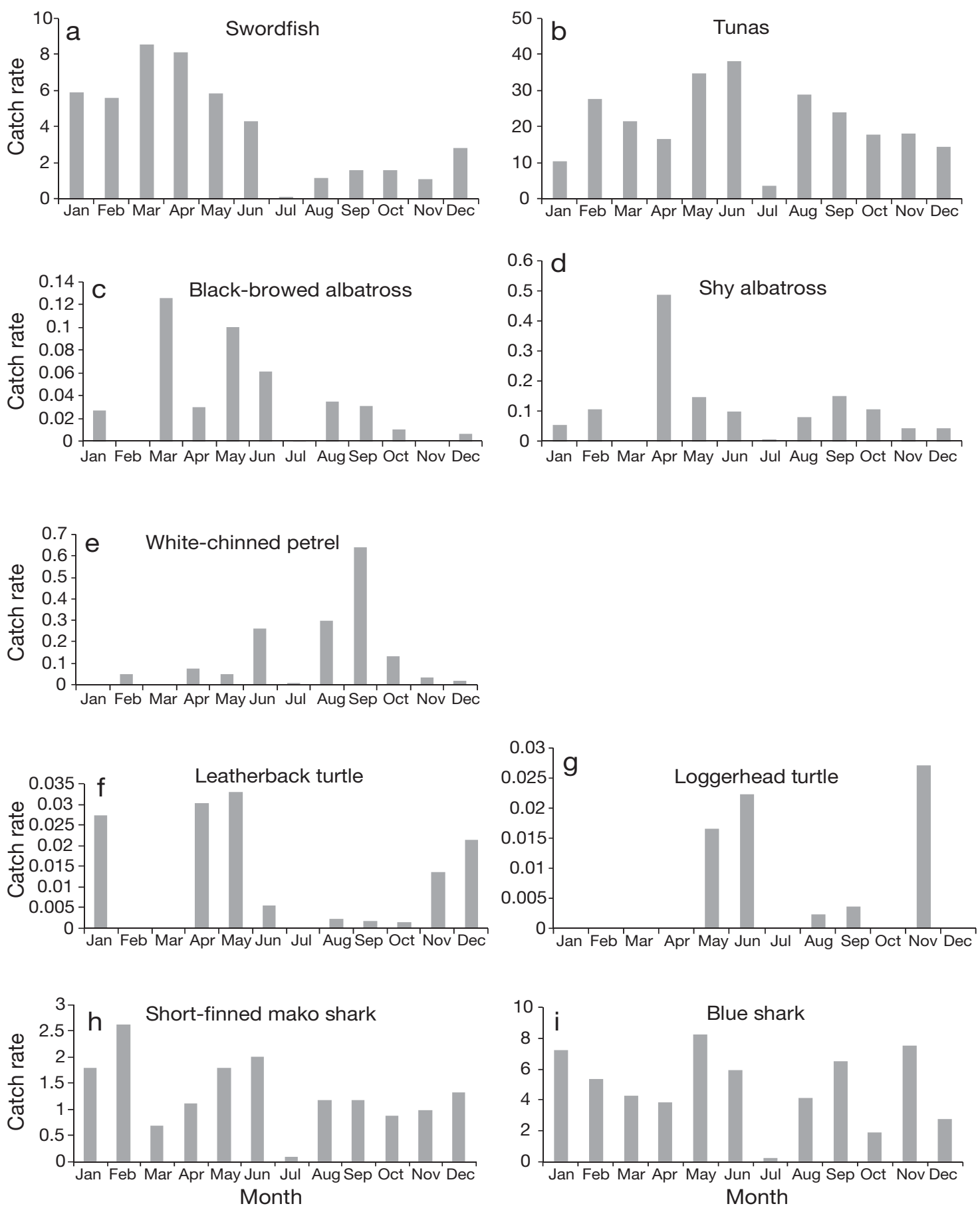

Fig. 2. Temporal catch rates for bycatch species. Catch rates were based on the monthly average (per 1000 hooks)

least effect on the longlining industry (Fig. 5). This was followed by permanent spatial closures, then temporary closures. This difference is greatest between temporary closures and the other 2 approaches when the bycatch reduction target is high. A $50 \%$ reduction target could be achieved using temporary spatial closures for a similar cost to a $30 \%$ reduction target for permanent spatial closures. Temporary spatial closures also require fewer sites. For example, using a permanent spatial closure and a $50 \%$ bycatch reduction target, 15 sites are required (Fig. 4b). However, for a temporary spatial closure, depending on the months, between 1 and 12 sites are required (Fig. 6). 


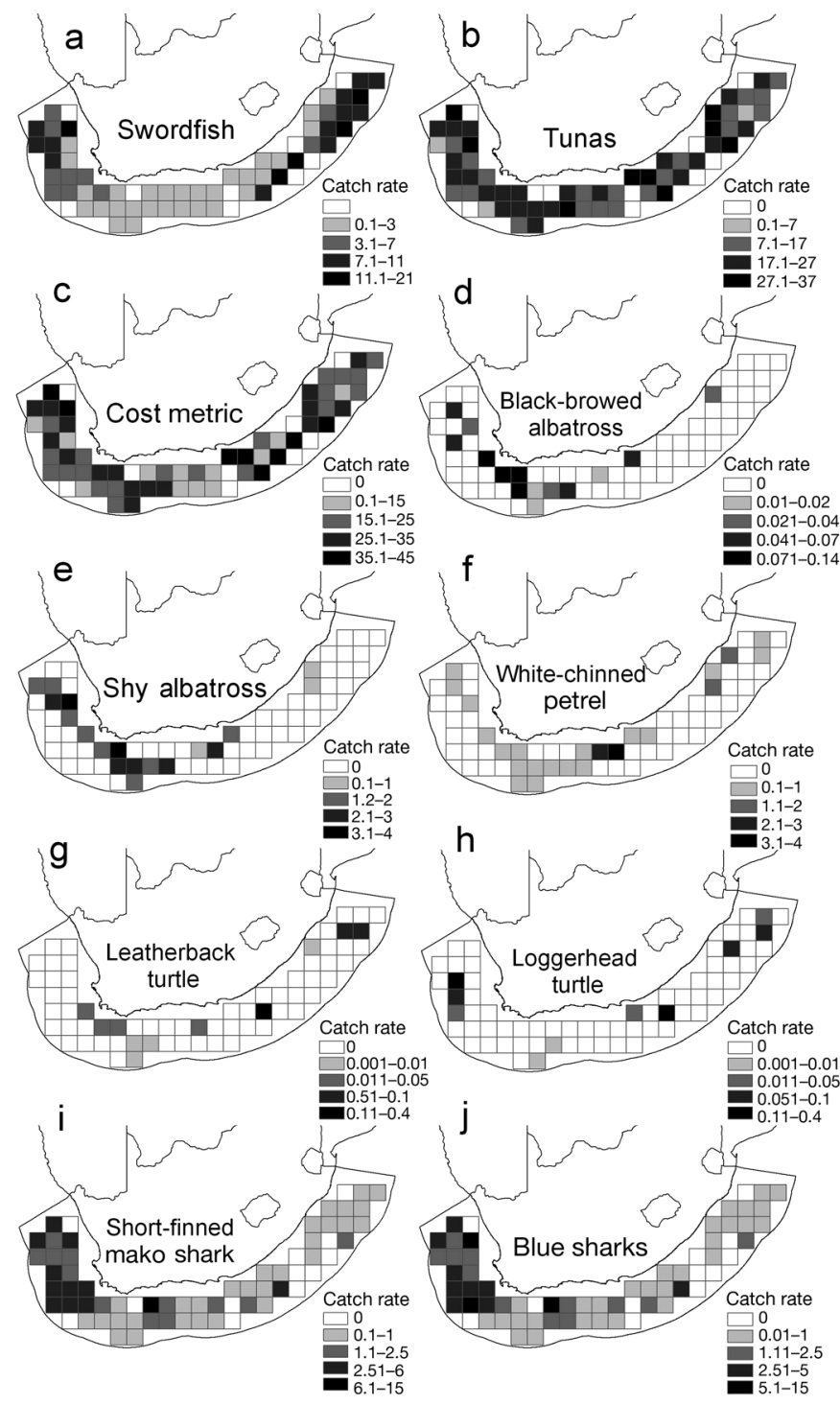

Fig. 3. Spatial distribution of species catch rates (per 1000 hooks) and cost metric. Cost metric was based on the summed catch rates of swordfish and tunas

\section{DISCUSSION}

We found that temporary spatial closures were the most effective strategy, as they achieved the required reduction in bycatch for the minimum cost to the longline fishery. This is to be expected, mathematically, because the control variables for the other 2 methods are a mere subset of the full set of control variables for the temporary spatial closures. For temporary closures there were only 12 control variables, which were each month. This was compared to 65 variables for permanent spatial closures and 780 for temporary spatial closures. In essence, temporary spatial closures provide more options to achieve a better result. More flexibility
Table 1. Temporal closures for different bycatch reduction targets

\begin{tabular}{|lccc|}
\hline Month & $30 \%$ & $50 \%$ & $80 \%$ \\
\hline January & 1 & 1 & 1 \\
February & 0 & 0 & 1 \\
March & 0 & 0 & 1 \\
April & 0 & 1 & 1 \\
May & 1 & 1 & 1 \\
June & 0 & 1 & 1 \\
July & 0 & 0 & 0 \\
August & 0 & 0 & 1 \\
September & 1 & 1 & 1 \\
October & 0 & 0 & 0 \\
November & 1 & 0 & 1 \\
December & 0 & 0 & 0 \\
\end{tabular}

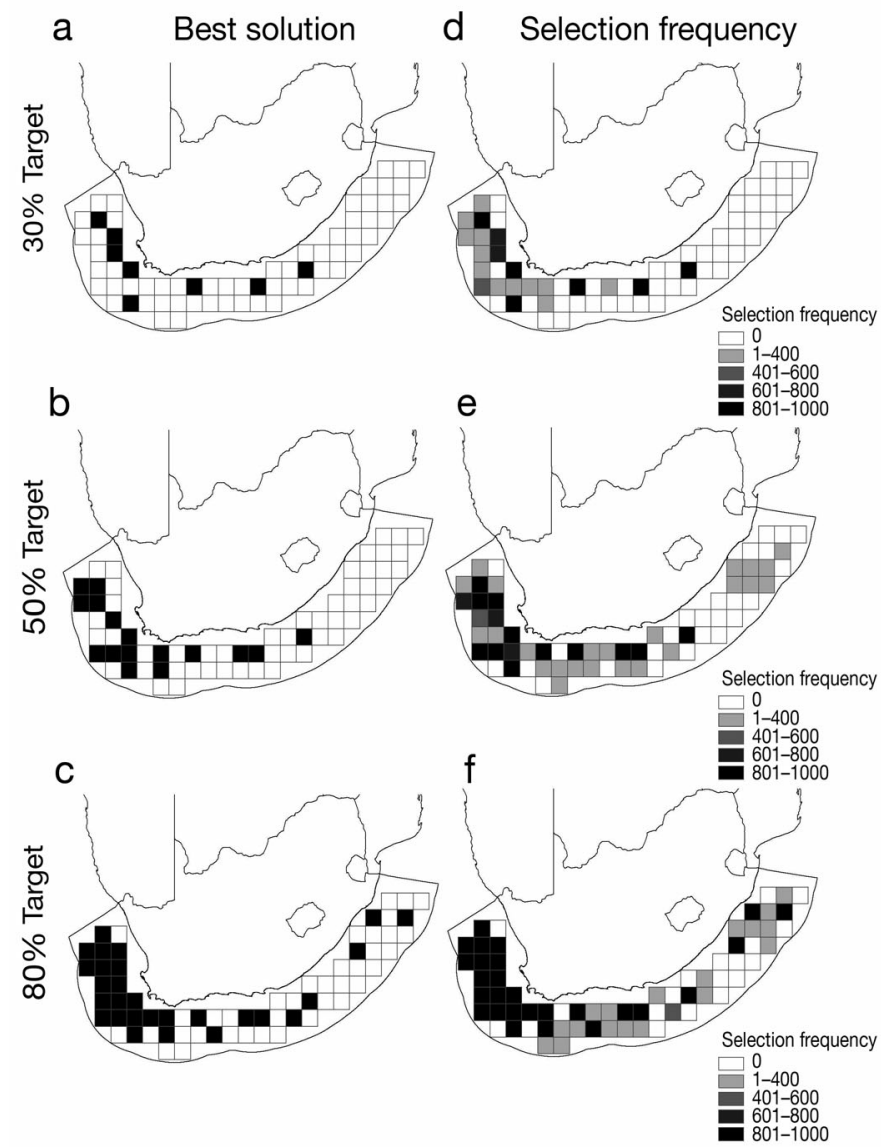

Fig. 4. Permanent spatial closures. For each scenario we ran the analysis 1000 times. We presented the output in 2 ways: $(\mathrm{a}-\mathrm{c})$ using best solution of the 1000 runs; (d-f) using the selection frequency, which is the number of times a site (candidate area for selection) was selected across the 1000 runs. We varied our analysis by using different bycatch reduction targets based on catch rates. Targets are $(\mathrm{a}, \mathrm{d}) 30 \%$, (b,e) $50 \%$ and $(\mathrm{c}, \mathrm{f}) \mathbf{8 0} \%$ 


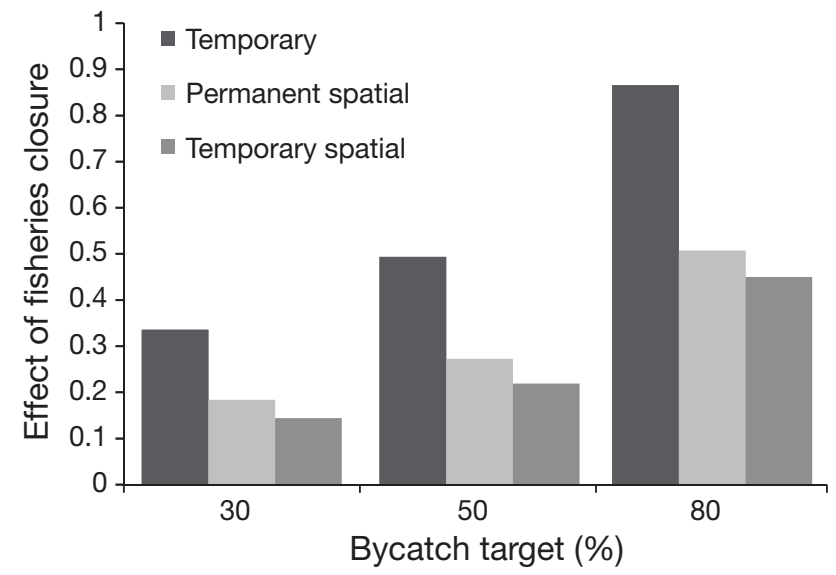

Fig. 5. Effect of 3 types of fisheries closures (temporary, permanent spatial and temporary spatial) on the longline fishery for different bycatch targets. The effect is calculated by dividing the cost of the solution with the total cost of sites and/or months
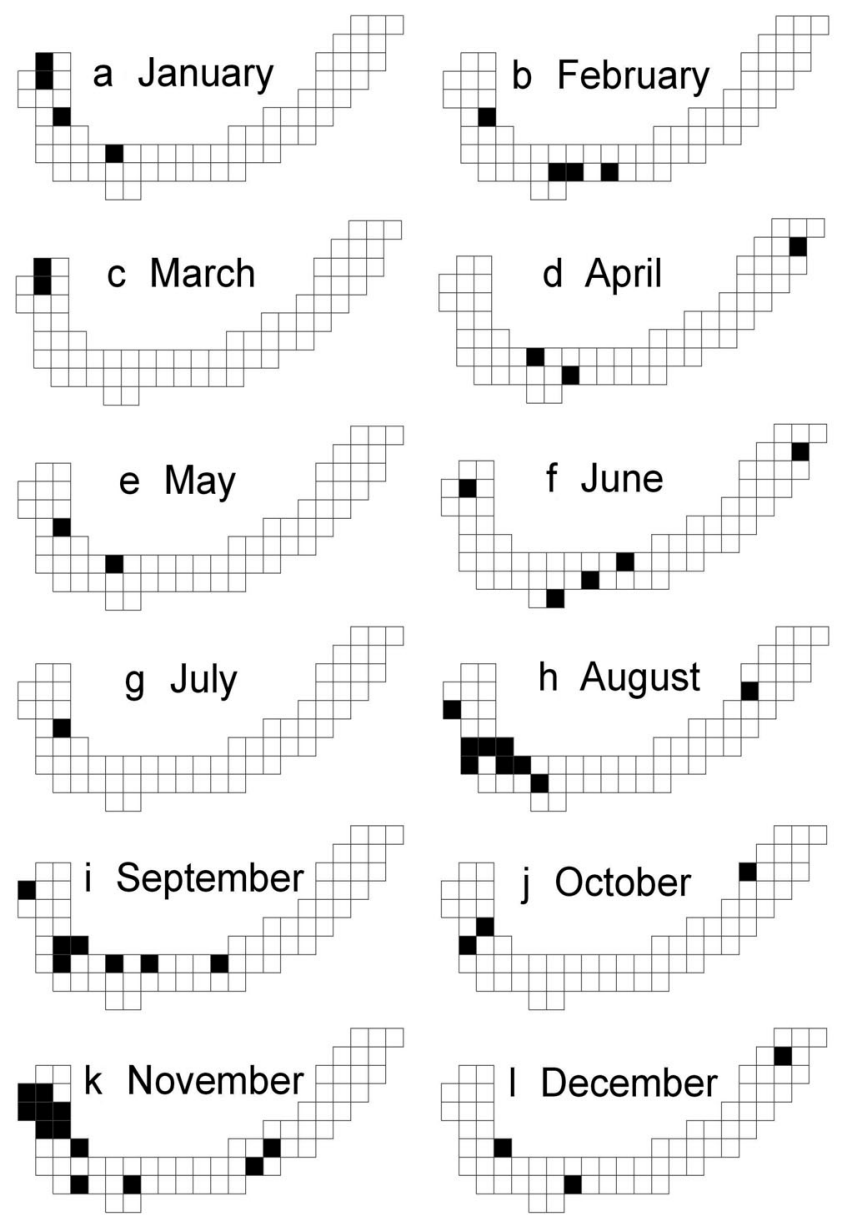

Fig. 6. Temporary spatial closures. The analysis was run based on selecting the best combination of sites and months to achieve a $50 \%$ bycatch target. The solution is across all months (a-l) will lead to more efficient solutions. However, these benefits need to be traded off against the costs and problems of implementing temporary spatial closures.

\section{Designing closures for spatially and temporally dynamic species}

All 7 bycatch species varied in when and where they were predominantly caught. Sub-Antarctic birds, such as black-browed albatross, shy albatrosses and whitechinned petrels, migrate to southern Africa in their non-breeding months to forage (Ryan et al. 2002, Baker et al. 2007). This overlaps somewhat with the period when they are most likely to be caught in this region, which for most of these species was between April and October. These birds are known to aggregate on the continental shelf and shelf break (Ryan et al. 2002, Baker et al. 2007), which explains the higher catch rates in that region. The west and south coasts appear to be the most important areas for albatrosses, whereas white-chinned petrels were caught also along the east coast. Non-breeder birds are likely to remain in the area for much of the year.

Leatherback and loggerhead turtles arrive on the east coast during the summer months, December to February (Hughes 1989, Wright 2004), which partially explains their higher catch rates during this time. Although there are a handful of records showing that leatherback turtles travel down the west coast to South Africa from Angola and Gabon, the majority caught by the South African pelagic longline fishery are likely to be from the South African population (Carr \& Carr 1991, Luschi et al. 2003, 2006, Fretey et al. 2007). Postbreeding loggerhead turtles typically move northward into the Western Indian Ocean; therefore, loggerhead turtles caught outside of the breeding season are unlikely to be from the South African population and more likely to be from West African populations (Brongersma 1982, Luschi et al. 2006). Post-breeding leatherback and loggerhead turtles disperse widely in their non-breeding periods to disparate foraging grounds, probably because of differing food requirements (Luschi et al. 2006). Leatherbacks are typically ocean wanderers and those that have been tracked from the South African population moved south along the continental shelf break to the Agulhas Bank (Luschi et al. 2003, 2006). Loggerheads tend to remain close inshore, moving from breeding to residential foraging grounds with high site fidelity among individuals (Godley et al. 2003, Luschi et al. 2006).

There is very limited understanding of the seasonal movements of pelagic sharks (Holts \& Bedford 1993, Sepulveda et al. 2004). The distribution of short-finned mako and blue shark catches are consistent with their 
generalist habitat of epipelagic and littoral waters from the surface to depths of $500 \mathrm{~m}$ in the case of mako sharks, and oceanic and epipelagic in the case of blue sharks (Holts \& Bedford 1993, Sepulveda et al. 2004).

\section{Closures as a fisheries management tool}

We provided solution as selection frequencies (Fig. 4d-f). The advantage of selection frequencies is that they display the flexibility of the solution and provided an indication of alternative configurations of closures. Our approach to designing closures was systematic, transparent and can be adapted as more data becomes available on catch rates, on other species, different targets and alternative cost metrics that might better estimate the likely impact of closures on the longlining fishery. It could also be expanded to incorporate other fishing sectors and management actions.

Higher bycatch targets would increase the protection of bycatch, but this also results in an increase in cost to the longline fishery. Any closure is likely to affect the longline fishery economically. In particular, if closures were implemented around Cape Point, it could have significant economic consequences for the South African fishery. Cape Town is the most frequently used port for this fishery; closures in the area would therefore increase the commuting distance to fishing grounds and as a result wages and fuel costs. If closures included areas where other fisheries occurred, such as demersal longline and trawl fisheries that are known to catch a similar suite of seabird species, these fisheries could also be significantly affected. We did not use size of area as a measurement of cost. In such a case, the design of closures would probably have had a greater impact on the fishery, as selection would not specifically minimize the impact on fisheries.

The true effectiveness of any closures in reducing bycatch is uncertain for several reasons. Given the large movements of all these species, it is possible that species might be simply caught outside closures. Additionally, some seabirds feed on fisheries discards and, consequently, the presence of fishing vessels has been identified as an important determinant of their distribution (Wahl \& Heinemann 1979, Ryan \& Moloney 1988, Furness et al. 1992, Garthe 1997, Votier et al. 2004). For example, the results of a tracking analysis in South African waters suggest that the presence of trawlers can be a strong predictor of both black-browed and shy albatrosses (S. Petersen unpubl. data). If trawlers are allowed within these closures, scavenging seabirds may simply follow trawling vessels out of a longline closed area. A further impediment to area closures is that displaced fishing effort may not reduce the bycatch of vulnerable species overall because of increased fishing intensity outside the closures; thus, overall fishing effort might need to be reduced. Also, complementary management actions such as the use of tori lines, night setting and weighted gear should be implemented simultaneously (Brothers et al. 1999). Lastly, many of these species move outside of South African waters, so even with adequate protection within South Africa, these species could continue to decline in other regions without protection or mitigation measures in other countries and on the high seas.

The high spatial overlap between fisheries catch of target and bycatch species is likely because many of these species tend to aggregate in areas of high productivity (Piontkovski et al. 1995, Pakhomov \& McQuaid 1996, Ansorge et al. 1999, Polovina et al. 2004). It is because of this behavior that species such as tuna and swordfish can be exploited at economically viable levels (Norse 2006). While some highly productive areas are fixed in space, such as areas near the shelf break, others are dynamic both spatially and temporally (Hyrenbach et al. 2000). Adequate protection might, therefore, often require large areas to be closed to fishing to account for this variability but large closures could have undesirable economic consequences (Angel 1993, Horwood et al. 1998, Boersma \& Parrish 1999, Botsford et al. 2003, Alpine \& Hobday 2007). As an alternative to fixed closures, we have shown that moveable closures may help reduce the impact to fisheries of bycatch protection. As an alternative to designing moveable closures using catch rates, Hobday \& Hartman (2006) describe a dynamic management approach using oceanographic features known to influence the distribution of the species of interest that is implemented in eastern Australia. In South Africa closed areas based on dynamic features such as mesoscale eddies, where nutrients, and consequently, top predators feed, could be implemented. The movement of the dynamic features could be tracked on satellites to determine where management areas would be located.

\section{CONCLUSION}

Closures are likely to be a useful management tool for ecosystem-based fisheries management. We have explored the utility of 3 types of different fishery closures to help reduce bycatch in the South African Pelagic Longline Fishery. We have shown that temporary spatial closures would be the most effective strategy for both protecting bycatch and minimizing the cost to fishers, as this method takes into account the spatial and temporal dynamics of the species of interest. The second best strategy is permanent spatial clo- 
sures, with the least effective being temporal closures. Implementation of closures is likely to have wider benefits of ecosystem protection, for example to species not considered in our analysis, but will have economic consequences for the longline fishery. Even if closures were implemented, without complementary management strategies that help mitigate bycatch, such as gear type restrictions and coordinated conservation management outside of South Africa in areas where these species migrate, there is likely to be a continued decline in the persistence of these species.

Acknowledgements. The data used in this paper were made available by Marine and Coastal Management, Department of Environmental Affairs and Tourism, South Africa and the Albatross Task Force, BirdLife International. A special thank you to the fisheries observers who collected this information. Financial support was received from the BCLME (Benguela Current Large Marine Ecosystem) Programme, WWF, BirdLife International and IAATO (International Association of Antarctic Tour Operators), the Albatross Task Force, BirdLife International, the Percy FitzPatrick Institute for African Ornithology and the National Research Foundation. This manuscript was substantially improved with comments by A. Hobday and 4 anonymous reviewers.

\section{LITERATURE CITED}

Alpine JE, Hobday AJ (2007) Area requirements and pelagic protected areas: Is size an impediment to implementation? Mar Freshw Res 58:558-569

Angel MV (1993) Biodiversity of the pelagic ocean. Conserv Biol 7:760-772

Ansorge IJ, Froneman PW, Pakhomov EA, Lutjehams JRE, Perissinotto R, van Ballegooyen RC (1999) Physical-biological coupling in the waters surrounding the Prince Edward Islands (Southern Ocean). Polar Biol 21:135-145

Baker GB, Double MC, Gales R, Tuck GN and others (2007) A global assessment of the impact of fisheries-related mortality on shy and white-capped albatrosses: Conservation implications. Biol Conserv 137:319-333

Barker MJ, Schleussel V (2005) Managing global shark fisheries: suggestions for prioritising management strategies. Aquat Conserv: Mar Freshw Ecosyst 15:325-347

Boersma PD, Parrish HJK (1999) Limiting abuse: marine protected areas, a limited solution. Ecol Econ 31:287-304

Botsford LW, Castilla JC, Peterson CH (1997) The management of fisheries and marine ecosystems. Science 277: 509-515

Botsford LW, Micheli F, Hastings A (2003) Principles for the design of marine reserves. Ecol Appl 13:25-31

Brongersma LD (1982) Marine turtles of the eastern Atlantic Ocean. In: Bjorndal K (ed) Biology and conservation of turtles. Smithsonian Institution Press, Washington, DC, p 407-416

Brothers NP, Cooper J, Løkkeborg S (1999) The incidental catch of seabirds by longline fisheries: worldwide review and technical guidelines for mitigation. Preliminary version. FAO Fish Circ No. 937. FAO, Rome

> Carr T, Carr N (1991) Surveys of the turtles of Angola. Biol Conserv 58:19-29

> Carr MH, Neigel JE, Estes JA, Andelman S, Warner RR, Largier JL (2003) Comparing marine and terrestrial eco- systems: implications for the design of coastal marine reserves. Ecol Appl 13:90-107

Croxall JP, Gales R (1998) An assessment of the conservation albatrosses. In: Robertson GR (eds) Albatrosses biology and conservation. Surrey Beatty \& Sons, Chipping Norton

Fretey J, Billes A, Baxter B, Hughes C (2007) Discovery of a Gabonese leatherback in South Africa. Mar Turtle Newsl 116:25

Furness RW, Ensor K, Hudson AV (1992) The use of fishery waste by gull populations around the British Isles. Ardea 80:105-113

Game ET, Grantham H (2008) Marxan user manual for Marxan version 1.8.10. University of Queensland, St. Lucia and Pacific Marine Analysis and Research Association, Vancouver

Garthe S (1997) Influence of hydrogaphy, fishing activity, and colony location on summer seabird distribution in the south-eastern North Sea. ICES J Mar Sci 54:566-577

Gell FR, Roberts CM (2003) Benefits beyond boundaries: the fishery effects of marine reserves. Trends Ecol Evol 18: 448-455

Gilman E, Clarke S, Brothers N, Alfaro-Shigueto J and others (2008) Shark interactions in pelagic longline fisheries. Mar Policy 32:1-18

Godley BJ, Broderick AC, Glen F, Hay GC (2003) Post-nesting movements and submergence patterns of loggerhead marine turtles in the Mediterranean assessed by satellite tracking. J Exp Mar Biol Ecol 287:119-134

> Halpern BS, Warner RR (2002) Marine reserves have rapid and lasting effects. Ecol Lett 5:361-366

> Hilborn R, Stokes K, Maguire JJ, Smith T, Botsford LW (2004) When can marine reserves improve fisheries management? Ocean Coast Manag 47:197-205

> Hobday AJ, Hartman K (2006) Near real-time spatial management based on habitat predictions for a longline bycatch species. Fish Manag Ecol 13:365-380

> Holts DB, Bedford DW (1993) Horizontal and vertical movements of the shortfin Mako shark, Isurus oxyrinchus, in the Southern California Bight. Aust J Mar Freshw Res 44: 901-909

Horwood JW, Nichols JH, Milligan S (1998) Evaluation of closed areas for fish stock conservation. J Appl Ecol 35:893-903

Hughes GR (1989) Turtles. In: Payne AIL, Crawford RJM (eds) Oceans of life off southern Africa. Vlaeberg Publishers, Cape Town, p 230-243

Hyrenbach DK, Forney KA, Dayton PK (2000) Marine protected areas and ocean basin managment. Aquat Conserv: Mar Freshw Ecosyst 10:437-458

Kock KH (2001) The direct influence of fishing and fisheryrelated activities on non-target species in the Southern Ocean with particularly emphasis on longline fishing and its impact on albatrosses and petrels: a review. Rev Fish Biol Fish 11:31-56

Lewison RL, Freeman SL, Crowder LB (2004) Quantifying the effects of fisheries on threatened species: the impacts of pelagic longlines on loggerhead and leatherback turtles. Ecol Lett 7:221-231

Luschi P, Sale A, Mencacci R, Hughes GR, Lutjeharms JRE, Papi F (2003) Current transport of leatherback turtles (Dermochelys coriacea) in the ocean. Proc R Soc Lond B Biol Sci 270(Suppl):129-132

Luschi P, Lutjeharms JRE, Lambardi P, Mencacci R, Hughes GR, Hays GC (2006) A review of migratory behaviour of turtles off southeastern Africa. S Afr J Sci 102:51-58

Mills CE, Carlton JT (1998) Rationale for a system of international reserves for the open ocean. Conserv Biol 12: $244-247$ 
Morishita J (2008) What is the ecosystem approach for fisheries management? Mar Policy 32:19-26

Myers RA, Worm B (2003) Rapid worldwide depletion of predatory fish communities. Nature 423:280-283

Norse EA (2005) Ending the range wars on the last frontier: zoning the sea. In: Norse EA, Crowder LB (eds) Marine conservation biology. The science of maintaining the sea's biodiversity. Island Press, Washington, DC, p 422-443

Pakhomov EA, McQuaid CD (1996) Distribution of surface zooplankton and seabirds across the Southern Ocean. Polar Biol 16:271-286

Petersen SL, Nel DC, Omardien A (2007). Towards an ecosystem approach to longline fisheries in the Benguela: an assessment on seabirds, seaturtles and sharks. WWF Report Series-2007/Marine/001

Pikitch EK, Santora C, Babcock EA, Bakun A and others (2004) Ecosystem-based fishery. Manag Sci 305: 346-347

Piontkovski SA, Williams R, Malnik TA (1995) Spatial heterogeneity, biomass and size structure of plankton of the Indian Ocean: some general trends. Mar Ecol Prog Ser 117:219-227

Polovina JJ, Balazs GH, Howell EA, Parker DM, Seki MP, Dutton PH (2004) Forage and migration habitat of loggerhead (Caretta caretta) and olive ridley (Lepidochelys olivacea) turtles in the central North Pactific Ocean. Fish Oceanogr 13:36-51

Possingham HP, Ball IR, Andelman S (2000) Mathematical methods for identifying representative reserve networks. In: Ferson S, Burgman M (eds) Quantitative methods for conservation biology. Springer-Verlag, New York, p 291-305

Editorial responsibility: Sascha Hooker,

St. Andrews, UK
Roberts CM, Hawkins JP, Gell FR (2005) The role of marine reserves in achieving sustainable fisheries. Philos Trans $\mathrm{R}$ Soc Lond B 360:123-132

> Ryan PG, Moloney CL (1988) Effect of trawling on bird and seal distributions in the southern Benguela region. Mar Ecol Prog Ser 45:1-11

Ryan PG, Keith DG, Kroese M (2002) Seabird bycatch by tuna longline fisheries off southern Africa, 1998-2000. S Afr J Sci 24:103-110

Sepulveda CA, Kohin S, Chan C, Vetter R, Graham JB (2004) Movement patterns, depth preferences, and stomach temperatures of free-swimming juvenile mako shark, Isurus oxyrinchus, in the Southern California Bight. Mar Biol 145:191-199

Smith ADM, Fulton EJ, Hobday AJ, Smith DC, Shoulder P (2007) Scientific tools to support practical implementation of ecosystem based fisheries management. ICES J Mar Sci 64:633-639

Votier SC, Furness RW, Bearhop S, Crane JE and others (2004) Changes in fisheries discard rates and seabird communities. Nature 427:727-730

Wahl TR, Heinemann D (1979) Seabirds and fishing vessels: co-occurrence and attraction. Condor 81:390-396

Worm B, Lotze HK, Myers RA (2003) Predator diversity hotspots in the blue ocean. Proc Natl Acad Sci USA 100: 9884-9888

Wright RV (2004) Forty years monitoring conservation of loggerhead and leatherback turtles in South Africa: successes and failures. MSc thesis, Oceanography Department, University of Cape Town

Submitted: April 30, 2008; Accepted: October 8, 2008 Proofs received from author(s): November 19, 2008 